\title{
PERBANDINGAN KINERJA REKSADANA SYARIAH DI INDONESIA MENGGUNAKAN METODE SHARPE (Studi Kasus Reksadana Syariah Saham, Reksadana Syariah Pendapatan Tetap dan Reksadana Syariah Campuran periode 2012-2014) ${ }^{1]}$
}

\author{
Bintang Pratama Buana Putra \\ Program Studi Ekonomi Islam-Fakultas Ekonomi dan Bisnis-Universitas Airlangga \\ Email: bintangpbp@gmail.com \\ Imron Mawardi \\ Departemen Ekonomi Syariah-Fakultas Ekonomi dan Bisnis-Universitas Airlangga \\ Email: imron.mawardi@gmail.com
}

\begin{abstract}
:
This research aims to find out the comparison between the performance of Islamic mutual funds of stock, Islamic mutual funds of fixed income and combined Islamic mutual funds. The method of this measuring calculates upon the risk factors and the return rate of those three kinds of Islamic mutual fund. This research uses 21 samples of Islamic mutual fund in Indonesia which consist of seven Islamic mutual funds of stock, seven Islamic mutual funds of fixed income and seven combined Islamic mutual funds. The approach used is a quantitative approach with the analysis technique of ANOVA. The result of this study shows that there is no difference between the performances of Islamic mutual funds of stock, Islamic mutual funds of fixed income and combined Islamic mutual funds on the period of January 2012 until December 2014 which has been analyzed using Sharpe method.
\end{abstract}

\section{Keywords : Islamic Mutual Funds of Stock, Islamic Mutual Funds of Fixed Income, Combined Islamic Mutual Funds, Sharpe Method.}

\section{Pendahuluan}

Pada masa sekarang, pasar modal merupakan salah satu pilihan untuk tempat investasi. Dalam pasar modal itu sendiri, terdapat berbagai macam instrumen keuangan yang dapat diperjual belikan, contohnya saja saham, obligasi dan sekuritas lainnya. Investor, menanamkan modalnya di instrumen keuangan tersebut dengan tujuan mendapatkan imbal hasil dari dana yang telah di investasikan.

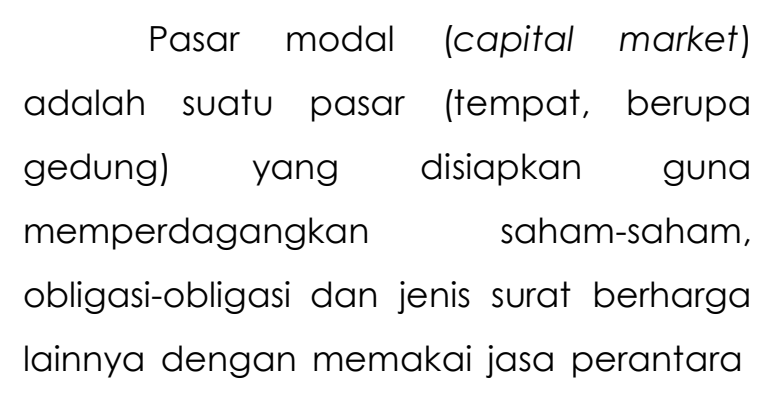
pedagang efek (Sunariyah, 2006:4).
Tetapi, investasi dalam efek di pasar modal mempunyai resiko yang lebih besar dibandingkan menempatkan dana pada deposito. Untuk memperkecil resiko tersebut, bisa dilakukan dengan diversifikasi investasi pada berbagai macam efek. Namun, investor yang memiliki dana terbatas, tidak mungkin bisa melakukan diversifikasi dikarenakan keterbatasan modal. Oleh karena itu, muncul reksadana yang merupakan salah satu alternatif untuk memperoleh pendapatan yang kompetitif.

$$
\text { Hadirnya reksadana syariah, }
$$
melengkapi keanekaragaman reksadana, dan menjadi pilihan investasi bagi para pemodal, khususnya pemodal muslim.

1) Jurnal ini merupakan bagian dari skripsi dari Bintang Pratama Buana. NIM 04121 1432031, yang diuji pada 12 Februari 2016 
Putra, et al/Jurnal Ekonomi Syariah Teori dan Terapan Vol. 3 No. 9 September 2016: 683-698; PERBANDINGAN KINERJA REKSADANA SYARIAH DI INDONESIA MENGGUNAKAN METODE SHARPE (Studi Kasus Reksadana Syariah Saham, Reksadana Syariah Pendapatan Tetap dan Reksadana Syariah Campuran periode 2012-2014)

Menurut Fatwa DSN (Dewan Syariah Nasional) MUI No.20/DSN MUI/IX/2000 menjelaskan reksadana syariah adalah reksadana yang beroperasi menurut ketentuan dan prinsip syariah Islam, baik dalam bentuk akad antara pemodal dengan manajer investasi sebagai wakil pemodal, maupun antara manajer investasi sebbagai wakil pemodal dengan pengguna investasi.

Perbedaan yang mendasar antara reksadana syariah dengan reksadana konvensional adalah reksadana syariah menginvestasikan dana yang telah terkumpul ke saham yang terdaftar di JII, obligasi syariah, dan instrumen keuangan syariah lainnya untuk dibentuk sebagai portofolio syariah.

Perkembangan pasar modal syariah, memberikan dampak positif pada perkembangan reksadana syariah. Hasbi (2010) menjelaskan berbagai macam jenis reksadana syariah muncul, diantaranya yaitu reksadana syariah saham, reksadana syariah pendapatan tetap, reksadana syariah campuran dan reksadana syariah terproteksi.

Dalam penelitian ini, subjek penelitian yang diteliti adalah reksadana syariah saham, reksadana syariah pendapatan tetap, dan reksadana syariah campuran.

Net Assset Value (NAV) atau nilai aktiva bersih (NAB) merupakan alat ukur kinerja reksadana. Nilai aktiva bersih berasal dari nilai portofolio reksadana yang bersangkutan (Sudarsono, 2004:208).

Seperti kita ketahui bahwa aktiva atau kekayaan reksadana berupa kas, deposito, SBPU, SBI, surat berharga komersial, saham, obligasi, right, dan efek lainnya.

Apabila terjadi perubahan nilai positif pada NAB suatu reksadana, hal itu menunjukkan peningkatan nilai NAB pada reksadana tersebut. Dan sebaliknya, apabila bernilai negatif, maka terjadi penurunan nilai NAB pada reksadana tersebut (Achsien, 2000:75).

Namun, NAB hanya memberikan informasi harian atas suatu portofolio reksadana itu sendiri. Investor tidak bisa melihat secara langsung perbandingan kinerja terhadap reksadana lain. Bila menggunakan NAB saja, investor bisa memperoleh informasi yang keliru. Contohnya, apabila suatu reksadana memiliki NAB tinggi di beberapa periode tanpa memperhitungkan tingkat resiko yang dimiliki, investor tersebut bisa menarik kesimpulan bahwa reksadana tersebut menguntungkan.

Pada umumnya, banyak investor yang belum mengetahui hubungan antara return dan resiko, kebanyakan dari mereka hanya membentuk portofolio Reksa Dana secara acak tanpa melakukan analisis terlebih dahulu. Mereka terlalu percaya pada manajer investasi yang mengelola dana mereka (Pinastiko dan Musaroh, 2014). Selain itu ada juga kaidah syariah tentang imbal hasil dan resiko adalah "al ghunmu bil ghumri", artinya resiko akan selalu menyertai setiap ekspetasi return (investasi) atau imbal hasil. Oleh karena itu, dalam mengukur kinerja reksadana tidak hanya dilihat dari return yang akan 
Putra, et al/Jurnal Ekonomi Syariah Teori dan Terapan Vol. 3 No. 9 September 2016: 683-698; PERBANDINGAN KINERJA REKSADANA SYARIAH DI INDONESIA MENGGUNAKAN METODE SHARPE (Studi Kasus Reksadana Syariah Saham, Reksadana Syariah Pendapatan Tetap dan Reksadana Syariah Campuran periode 2012-2014)

didapatkan, melainkan juga harus memperhitungkan besar resiko yang akan diterima

Terdapat beberapa metode yang termasuk risk adjusted return, yaitu metode sharpe, metode treynor, dan metode jensen. Eduardus Tandelilin (2010:494) menjelaskan bahwa metode sharpe mendasarkan perhitungan pada konsep garis pasar modal sebagai patok duga, yaitu dengan cara membagi premi resiko portofolio dengan standar deviasinya (resiko total), sehingga bisa mengukur premi resiko untuk setiap unit resiko pada portofolio tersebut

Berkaitan dengan latar belakang di atas, penelitian ini bertujuan untuk membandingkan kinerja reksadana syariah saham, resadana syariah pendapatan tetap dan reksadana syariah campuran menggunakan metode sharpe periode 2012 - 2014.

Berdasarkan uraian yang telah dijelaskan maka peneliti dapat merumuskan masalah penelitian sebagai berikut Bagaimana kinerja reksadana syariah (saham, pendapatan tetap, dan campuran) menggunakan metode Sharpe? Apakah terdapat perbedaan kinerja reksadana syariah (saham, pendapatan tetap, dan campuran) menggunakan metode Sharpe?

Adapun tujuan penelitian ini untuk menganalisis kinerja reksadana syariah (saham, pendapatan tetap, dan campuran) menggunakan metode sharpe. Selain itu juga bertujuan untuk menganalisis perbedaan kinerja reksadana syariah (saham, pendapatan tetap, dan campuran) menggunakan metode sharpe

\section{LANDASAN PUSTAKA}

Menurut Sofiniyah

(2005:15) menjelaskan reksadana dalam hal ini memiliki pengertian yang sama dengan reksadana konvensional, hanya saja cara pengelolaan dan kebijakan investasinya harus berdasarkan pada syariat Islam, baik dari segi akad, pelaksanaan investasi, maupun dari segi pembagian keuntungan. Menurut Tedy (2002:89) menjelaskan reksadana syariah memiliki kebijakan investasi yang berbasis pada prinsip-prinsip Islam. Instrumen investasi yang dipilih dalam portofolionya harus dikatakan halal.

Menurut Sudarsono

(2004:200)

menyimpulkan:

Reksadana Syariah adalah reksadana yang pengelolaan dan kebijakan investasinya berpedoman pada syariah Islam. Portofolionya hanya berinvestasi pada instrumen yang sesuai dengan syariah, yaitu bebas dari unsur maysir, gharar, dan riba. Reksadana Syariah tidak menginvestasikan dananya pada perusahaan yang pengelolaan dan produknya bertentangan dengan syariat Islam. Seperti pabrik makanan atau minuman yang mengandung alkohol, daging babi, rokok tembakau, jasa keuangan konvensional, pertahanan dan persenjataan serta bisnis hiburan yang berbau maksiat.

Menurut Fatwa DSN (Dewan Syariah Nasional) MUI No.20/DSN MUI/IX/2000 menyatakan definisi 
Putra, et al/Jurnal Ekonomi Syariah Teori dan Terapan Vol. 3 No. 9 September 2016: 683-698; PERBANDINGAN KINERJA REKSADANA SYARIAH DI INDONESIA MENGGUNAKAN METODE SHARPE (Studi Kasus Reksadana Syariah Saham, Reksadana Syariah Pendapatan Tetap dan Reksadana Syariah Campuran periode 2012-2014)

reksadana syariah sebagai reksadana yang beroperasi menurut ketentuan dan prinsip syariah Islam, baik dalam bentuk akad antara pemodal (Shahib al-mal/Rab al-mal) dengan manajer investasi sebagai wakil shahib al-mal, maupun antara manajer investasi sebbagai wakil shahib al-mal dengan pengguna investasi

Dari pengertian diatas menurut (DSN, 2001: 38) dapat dipahami bahwa dalam reksadana terkandung empat unsur utama, yaitu:

1. Masyarakat pemilik modal (shahib al maal/ rab al maal).

2. Modal yang disetor (al maal).

3. Manajer investasi sebagai pengelola modal (wakil shahib al maal).

4. Investasi yang dilakukan oleh manajer investasi (,amal).

Menurut Hasbi (2010) menjelaskan ada beberapa jenis reksadana syariah. investor dalam berinvestasi dapat memilih 4 jenis reksadana berbasis syariah, antara lain:

1. Reksadana syariah saham, yaitu reksadana yang menginvestasikan dananya ke efek syariah bersifat ekuitas. Jenis reksadana ini menawarkan imbal hasil yang tertinggi jika dibandingkan reksadana lainnya. Tentunya, imbal hasil yang tinggi ini juga diimbangi oleh tingkat resiko yang cukup tinggi.

2. Reksadana syariah campuran, yaitu reksadana yang menempatkan investasi dalam efek syariah bersifat ekuitas dan hutang. Reksadana jenis ini lebih aman pada kondisi pasar dimana terjadi volatilitas yang cukup tinggi dikarenakan investasi di tempatkan diberbagai instrumen, baik itu saham, obligasi, maupun pasar vang.

3. Reksadana syariah pendapatan tetap, yaitu reksadana yang menawarkan imbal hasil terendah jika dibandingkan beberapa reksadana lainnya. Namun, tingkat resiko yang ditawarkan juga rendah.

4. Reksadana syariah terproteksi, yaitu reksadana yang memberikan proteksi sebesar $100 \%$ dari nilai investasi awal dengan syarat dan ketentuan khusus yang berlaku. Reksadana ini cenderung diinvestasikan pada instrumen pasar modal dan pasar vang yang lebih aman.

Sudarsono (2004:201) menyatakan "Net Assset Value (NAV) atau nilai aktiva bersih (NAB) merupakan alat ukur kinerja reksadana. Nilai aktiva bersih berasal dari nilai portofolio reksadana. Aktiva atau kekayaan reksadana bisa dilihat pada kas, deposito, saham, obligasi, dan surat berharga lainnya".

NAB merupakan jumlah aktiva setelah dikurangi kewajiban-kewajiban yang ada, sedangkan NAB per unit penyerta merupakan jumlah NAB dibagi dengan jumlah nilai unit penyerta yang beredar dan NAB per unit saham dihitung setiap 
Putra, et al/Jurnal Ekonomi Syariah Teori dan Terapan Vol. 3 No. 9 September 2016: 683-698; PERBANDINGAN KINERJA REKSADANA SYARIAH DI INDONESIA MENGGUNAKAN METODE SHARPE (Studi Kasus Reksadana Syariah Saham, Reksadana Syariah Pendapatan Tetap dan Reksadana Syariah Campuran periode 2012-2014)

hari oleh bank kustodian setelah mendapat dana dari manajer investasi (Achsien, 2000:75).

Besarnya NAB dapat berfluktuasi setiap hari, tergantung pada perubahan nilai efek dan portofolio. Meningkatnya NAB mengindikasikan naiknya nilai investasi pemegang saham per unit penyertaan. Begitu juga sebaliknya menurun berarti berkurang nilai investasi pemegang unit penyertaan. Secara ringkas dapat ditulis rumus sebagai berikut: (Soemitra, 2009:188) menjelaskan total nilai aktiva bersih pada periode tertentu :

Total $\mathrm{NAB}=$ Nilai aktiva - Total kewajiban ... (2.1)

Nilai aktiva bersih per unit :

$\mathrm{NAB}$ Per Unit =

Total nilai aktiva bersih

Total unit penyertaan(saham) diterbitkan

Dimana:

Total $\mathrm{NAB}=$ Jumlah Nilai Aktiva Bersih pada periode tertentu

NAB Per Unit = Nilai Aktiva Bersih per saham atau unit penyertaan pada periode tertentu.

Untuk menghitung kinerja dengan metode sharpe, kita harus mencari dulu expected return. Menurut Jogiyanto (2010:205) menjelaskan return merupakan hasil yang diperoleh dari investasi. Return dapat berupa return realisasi yang sudah terjadi atau return ekspektasi yang belum terjadi tetapi yang diharapkan akan terjadi dimasa mendatang.

1. Return Realisasi (Realized Return)

Return realisasi merupakan return yang telah terjadi. Return realisasi dapat dihitung memlalui data histories. Return realisasi penting karena digunakan mengukur kinerja dari perusahaan. Return histories ini juga berfungsi sebagai dasar penentuan return ekspektasi dan resiko dimasa mendatang (Jogiyanto, 2010:205).

Return realisasi reksadana, Hamzah dan Yohanes (2014) menjelaskan dapat diukur dengan menggunakan rumus sebagai berikut: $\operatorname{Ri}(\operatorname{RDS}, \mathrm{RDPT})=\frac{\mathrm{t}-\mathrm{t}-1}{\mathrm{t}-1} \ldots \ldots . .(2.3)$

Dimana :

Ri $($ RDS, RDPT $)=$ Tingkat pengembalian portofolio

$N A B_{\dagger} \quad=$ Nilai aktiva bersih pada akhir periode $t$

$N A B_{t-1}=$ Nilai aktiva bersih pada awal periode $t$

2. Return Harapan (Expected Return)

Return harapan adalah return yang diharapkan oleh investor dimasa yang akan datang. Untuk mencari return harapan, (Eduardus Tandelilin, 2010 : 105) menyatakan dalam rumus: $E(R i)(R D S, R D P T)=\frac{(i)}{n}$

Dimana :

$E(R i)(R D S, R D P T)=$ Rata-rata pengembalian yang diharapkan.

$\mathrm{Ri}=$ Tingkat pengembalian portofolio

$\mathrm{n}=$ Jumlah periode selama transaksi

Setelah didapatkan hasil perhitungan expected return langkah selanjutnya adalah menghitung resiko. Resiko sering dihubungkan dengan penyimpangan atau deviasi dari outcome yang diterima dengan yang diekspektasi. 
Putra, et al/Jurnal Ekonomi Syariah Teori dan Terapan Vol. 3 No. 9 September 2016: 683-698; PERBANDINGAN KINERJA REKSADANA SYARIAH DI INDONESIA MENGGUNAKAN METODE SHARPE (Studi Kasus Reksadana Syariah Saham, Reksadana Syariah Pendapatan Tetap dan Reksadana Syariah Campuran periode 2012-2014)

Van Home dan Wachowich, Jr (1992) mendefinisikan resiko sebagai varibilitas return terhadap return yang diharapkan (Jogianto, 2010:124).

Menurut Abdul (2005:42) menyatakan:

"pengukuran variabilitas return yang paling umum digunakan adalah varians dan deviasi standar. Keduanya mengukur seberapa jauh return aktual berbeda dengan ratarata return. Varians mengukur ratarata selisih kuadrat antara return aktual dan rata-rata return".

Varian dan deviasi standar dihitung dengan rumus sebagai berikut:

$$
i^{2}=\frac{i-(i)^{2}}{n}
$$

Dimana :

$$
\begin{array}{ll}
i^{2} \quad & \text { Varian dari pengembalian } \\
& \text { Investasi } \\
\text { i } \quad & \text { Rata-rata pengembalian } \\
& \text { investasi } \\
\text { i } \quad=\text { Tingkat pengembalian portofolio } \\
n \quad=\text { Jumlah bulan yang digunakan } \\
\sqrt{2} \text {...............................(2.6) } \\
\text { Dimana : } \\
=\text { deviasi standar } \\
2 \quad \text { varian dari pengembalian investasi }
\end{array}
$$

Selain itu, kita juga harus menghitung tingkat pendapatan bebas resiko. Tingkat pendapatan bebas resiko SBIS didapat dari data Bank Indonesia. Data yang didapat adalah data tahunan maka harus dilakukan penyesuaian untuk mendapatkan data bulanan. Menurut Citrayani (2013) menjelaskan pendapatan investasi bebas resiko yaitu tingkat suku bunga yang diwakili oleh suku bunga sertifikat bank Indonesia syariah (SBIS). Cara mencari tingkat pendapatan bebas resiko dapat dicari dengan persamaan:
SBIS bulanan $=\frac{\text { Tahunan }}{12}$

Melihat kinerja sebuah portofolio tidak bisa hanya melihat tingkat return yang dihasilkan portofolio tersebut, tetapi kita juga harus memperhitungkan faktorfaktor lain seperti tingkat resiko portofolio tersebut (Tandelin, 2010 : 493). Dengan berdasarkan teori pasar modal, beberapa ukuran kinerja portofolio sudah memasukkan faktor return dan resiko dalam penghitungannya.

\section{Metode Sharpe} Metode sharpe dikembangkan oleh William Sharpe (1966) dan sering juga disebut dengan reward to variability ratio. Perhitungan metode sharpe didasarkan pada konsep garis pasar modal sebagai patok duga, caranya yaitu dengan membagi premi resiko portofolio (sama dengan selisih rata-rata tingkat keuntungan portofolio dengan rata-rata bunga bebas resiko) dengan standar deviasinya (resiko total) (Tandelin, 2010 : 493). Untuk menghitung metode sharpe dapat menggunakan persamaan berikut :

$S p(R D S, R D P T)=\frac{i-f}{i}$.

Dimana :

$\mathrm{Sp}(\mathrm{RDS}, \mathrm{RDPT})=$ Metode sharpe

portofolio

Ri $=$ Rata-rata return portofolio

investasi selama periode pengamatan

$\mathrm{Rf}=$ Rata-rata tingkat return bebas

resiko selama periode pengamatan

i = Standar deviasi return portofolio investasi selama periode pengamatan 
Putra, et al/Jurnal Ekonomi Syariah Teori dan Terapan Vol. 3 No. 9 September 2016: 683-698; PERBANDINGAN KINERJA REKSADANA SYARIAH DI INDONESIA MENGGUNAKAN METODE SHARPE (Studi Kasus Reksadana Syariah Saham, Reksadana Syariah Pendapatan Tetap dan Reksadana Syariah Campuran periode 2012-2014)

Premi resiko portofolio, Ri - Rf, merupakan kompensasi untuk memikul resiko. Sedangkan deviasi standar return potofolio adalah untuk mengukur resiko.

2. Metode Treynor

Metode treynor merupakan ukuran kinerja porofolio yang dikembangkan oleh Jack Treynor (1965) dan indeks ini sering disebut juga dengan reward to volatility ratio. Pada metode treynor kinerja portofolio dilihat dengan cara menghubungkan tingkat return portofolio dengan besarnya resiko dari portofolio tersebut. Tetapi, yang membedakannya metode sharpe adalah penggunaan garis pasar sekuritas sebagai patok duga dan bukan garis pasar modal seperti metode sharpe. Sedangkan asumsi yang digunakan oleh Treynor adalah portofolio sudah terdiversifikasi dengan baik sehingga resiko yang dianggap relevan adalah resiko sistematis (diukur dengan beta) (Tandelin, 2010 : 497). Metode treynor suatu portofolio dalam periode tertentu dapat dihitung dengan menggunakan persamaan berikut:

$T p(R D S, R D P T)=\frac{i-f}{i}$.

Dimana :

$T p($ RDS, RDPT $)=$ Metode treynor

portofolio

$\mathrm{Ri}=$ Rata-rata return portofolio investasi

selama periode pengamatan

$R f=$ Rata-rata tingkat return bebas

resiko selama periode pengamatan
$\mathrm{Bi}=$ Beta porotofolio investasi

3. Metode Jensen

Metode ini didasarkan pada konsep security market line yang merupakan garis yang menghubungkan portofolio pasar dengan kesempatan investasi bebas resiko yaitu persamaan garis yang melewati titik $(0, \mathrm{Rf})$ dan $(1, \mathrm{Rm})$. Garis security market line memperlihatkan hubungan antara systematic risk dan expected return dari suatu portofolio pada saat pasar dalam keadaan equilibrium. Jadi security market line merupakan kemiringan dari beta atau suatu garis regresi dengan interceptnya adalah Rf dan slopnya dinyatakan sebagai $[E(R m)-R f]$ atau Bm (Tandelin, $2010: 500)$.

Persamaan metode jensen dan metode treynor adalah sama-sama menggunakan garis pasar sekuritas. Sedangkan perbedaannya bahwa metode treynor sama dengan slope garis yang menghubungkan posisi portofolio dengan return bebas resiko, sedangkan indeks Jensen merupakan selisih antara return rata-rata dan return portofolio acuan (Tandelin, 2010 : 501).

Perbedaan ini biasanya disebut alfa atau differential return portofolio dan dinotasikan :

a ( i)- sml

atau

a (i)- $f((m)-f) i$

Berdasarkan uraian diatas, maka Jensen dapat dimodifikasi dengan menggunakan formula sebagai berikut: 
Putra, et al/Jurnal Ekonomi Syariah Teori dan Terapan Vol. 3 No. 9 September 2016: 683-698; PERBANDINGAN KINERJA REKSADANA SYARIAH DI INDONESIA MENGGUNAKAN METODE SHARPE (Studi Kasus Reksadana Syariah Saham, Reksadana Syariah Pendapatan Tetap dan Reksadana Syariah Campuran periode 2012-2014)

$$
\begin{aligned}
& a(D, D P T)=(R i-R f)-\quad(m \\
& R f)] \ldots \ldots \ldots \ldots \ldots(2.10)
\end{aligned}
$$

Dimana:

a ( D, DPT) alfa Jensen portofolio

$\mathrm{Ri}=$ rata-rata return portofolio investasi

$\mathrm{Rf}=$ rata-rata tingkat return bebas

resiko

$\mathrm{Rm}=$ rata-rata return pasar

$B=$ beta portofolio investasi

\section{Hipotesis}

Berdasarkan penjelasan latar belakang, rumusan masalah, tujuan penelitian, tinjauan pustaka, maka hipotesis dalam penelitian ini adalah :

$\mathrm{H}_{1}$ : Ada perbedaan kinerja antara reksadana syariah saham, reksadana syariah campuran, dan reksadana syariah pendapatan tetap dengan menggunakan metode sharpe pada tahun 2012, 2013, 2014.

\section{Model Analisis}

Model analisis yang digunakan adalah ANOVA untuk menemukan perandingan kinerja reksadana syariah (saham, pendapatan tetap dan campuran). Sebelumnya dilakukan pengujian kinerja reksadana syariah (saham, campuran, dan pendapatan tetap) yang lebih komperehensif dilakukan dengan melakukan analisis dari hasil perhitungan model risk adjusted performance yaitu metode sharpe. Setelah dilakukan perhitungan dengan menggunakan metode sharpe, dianalisis lebih lanjut menggunakan metode analisis statistik deskriptif. Analisis yang dilakukan dengan cara membandingkan rata - rata return reksadana syariah (saham, pendapatan tetap dan campuran) perhitungan metode sharpe dengan rata - rata return bebas resiko dan standar deviasinya (resiko total). Selanjutnya dilakukan uji normalitas dan homogenitas untuk memenuhi salah satu asumsi ANOVA yaitu data harus terdistribusi normal dan populasi memiliki standar deviasi yang sama. Selanjutnya, dilakukan uji ANOVA untuk mengetahui perbandingan kinerja reksadana syariah (saham, campuran, dan pendapatan tetap) periode 20122014.

\section{METODOLOGI PENELITIAN}

\section{Pendekatan Penelitian}

Penelitian ini menggunakan pendekatan kuantitatif untuk menjawab masalah yang telah dirumuskan sebelumnya dan memerlukan perhitungan yang bersifat matematis dengan menggunakan rumus statistik tertentu. Penelitian ini menitik beratkan pada pengujian hipotesis dan diharapkan menghasilkan suatu kesimpulan yang dapat digeneralisasikan

\section{Identifikasi Variabel}

Untuk menjawab rumusan masalah dan menguji hipotesis, maka variabel yang digunakan dalam penelitian ini adalah kinerja reksadana syariah sama menggunakan metode sharpe, kinerja reksadana syariah pendapatan tetap dengan metode sharpe, kinerja reksadana syariah campuran dengan metode sharpe.

\section{Definisi Operasional Variabel}

Untuk memberikan gambaran yang jelas mengenai variabel yang digunakan 
Putra, et al/Jurnal Ekonomi Syariah Teori dan Terapan Vol. 3 No. 9 September 2016: 683-698; PERBANDINGAN KINERJA REKSADANA SYARIAH DI INDONESIA MENGGUNAKAN METODE SHARPE (Studi Kasus Reksadana Syariah Saham, Reksadana Syariah Pendapatan Tetap dan Reksadana Syariah Campuran periode 2012-2014)

dalam penelitian ini, maka variabel tersebut dapat didefinisikan sebagai berikut:

1. Kinerja

Kinerja adalah sebuah hal yang menjadi tolok ukur, baik atau tidaknya, bertumbuh atau tidaknya suatu organisasi. Kinerja reksadana pada penelitian ini, mengacu pada kinerja portofolio yang dilakukan oleh reksadana dalam menginvestasikan dananya (Magdalena dan Amelina, 2012).

Untuk mengukur kinerja dalam penelitian ini, tidak hanya dilihat dari return yang dihasilkan oleh portofolio investasi. Melainkan juga memperhitungkan dari segi resiko. Seperti pendapat (Tandelilin, 2010:489) menjelaskan "kinerja portofolio harus memperhatikan apakah tingkat return portofolio yang diperoleh sudah cukup memadai untuk menutupi resiko yang harus ditanggung". tau dapat disimpulkan bahwa pengukuran portofolio tidak hanya dilihat dari besarnya return portofolio saja, tetapi juga harus memperhatikan besarnya resiko yang harus ditanggung untuk memperoleh besarnya return tersebut.

\section{Reksadana Syariah Saham}

Reksadana syariah saham, yaitu reksadana yang menginvestasikan dananya ke efek syariah bersifat ekuitas. Jenis reksadana ini menawarkan imbal hasil yang tertinggi jika dibandingkan reksadana lainnya. Tentunya, imbal hasil yang tinggi ini juga diimbangi oleh tingkat resiko yang cukup tinggi (Hasbi, 2010).
3. Reksadaana Syariah Pendapatan Tetap

Reksadana syariah pendapatan tetap, yaitu reksadana yang menawarkan imbal hasil terendah jika dibandingkan beberapa reksadana lainnya. Namun, tingkat resiko yang ditawarkan juga rendah (Hasbi, 2010)

4. Reksadana Syariah Campuran

Reksadana syariah campuran, yaitu reksadana yang menempatkan investasi dalam efek syariah bersifat ekuitas dan hutang. Reksadana jenis ini lebih aman pada kondisi pasar dimana terjadi volatilitas yang cukup tinggi dikarenakan investasi di tempatkan diberbagai instrumen, baik itu saham, obligasi, maupun pasar uang (Hasbi, 2010).

5. Metod Sharpe

Metode sharpe adalah perhitungan yang mendasarkan perhitungannya pada konsep garis pasar modal (capital market line) sebagai patok duga, yaitu dengan cara membagi premi resiko portofolio (sama dengan selisih rata-rata tingkat keuntungan portofolio dengan rata-rata bunga bebas resiko) dengan standar deviasinya (resiko total) (Tandelilin, 2010 : 494). Untuk menghitung metode sharpe dapat menggunakan persamaan (2.7)

\section{Jenis dan Sumber Data}

Dalam penelitian ini, keseluruhan datanya adalah data sekunder yang diperoleh dari Statistik Reksadana Syariah yang diterbitkan di ojk.go.id dan pusatdata.kontam.com yang diambil periode Januari 2012- Desember 2014. Selain itu Data tingkat imbal hasil SBIS dan 
Putra, et al/Jurnal Ekonomi Syariah Teori dan Terapan Vol. 3 No. 9 September 2016: 683-698; PERBANDINGAN KINERJA REKSADANA SYARIAH DI INDONESIA MENGGUNAKAN METODE SHARPE (Studi Kasus Reksadana Syariah Saham, Reksadana Syariah Pendapatan Tetap dan Reksadana Syariah Campuran periode 2012-2014)

SBI sebagai tolak ukur asset bebas resiko yang diperoleh dari situs Bank Indonesia yaitu www.bi.go.id. SBIS adalah instrumen moneter berdasarkan prinsip syariah yang dimanfaatkan oleh bank syariah mengatasi kelebihan likuidasinya. SBIS berlaku sejak maret 2008 setelah dihapuskannya SWBI. Data pada penelitian ini termasuk data panel dengan skala nominal.

\section{Populasi dan Sampel}

Sampel yang digunakan dalam penelitian ini dilakukan dengan metode purpose sampling yang berarti bahwa teknik pengambilan sampel bersifat tidak acak dimana sampel dipilih berdasarkan pertimbangan tertentu (Singarimbun dan Efendi, 1989:110). Pertimbangan diambil berdasarkan tujuan penelitian ini adalah berdasarkan kriteria sebagai berikut:

1. Reksadana syariah (saham, campuran dan pendapatan tetap) yang sudah tercatat di OJK

2. Reksadana yang selama periode penelitian (tahun 2012-tahun 2014) tidak dilikuidasi, tidak bubar, tidak merger, dan tercatat di OJK

3. Sampel yang diambil merupakan produk dari perusahaan reksadana syariah (saham, campuran, dan pendapatan tetap) yang Nilai Aktiva Bersih (NAB) dipublikasikan di media cetak minimal Januari 2012.

4. Data Nilai Aktiva Bersih (NAB) reksadana syariah (saham, campuran, dan pendapatan tetap) yang akan diambil sebagai sampel penulisan ini adalah data bulanan untuk tahun yang bersangkutan.

Dari kriteria tersebut, maka didapatkan sampel sebanyak 21 sampel, yang terdiri dari 7 reksadana syariah saham, 7 reksadana syariah campuran, dan 7 reksadana syariah pendapatan tetap.

\section{Teknik Analisis}

1. Menyajikan data NAB per unit dari masing-masing reksadana yang termasuk dalam reksadana saham, reksadana pendapatan tetap, dan reksadana campuran. Data NAB per unit diambil dari harga penutupan tiap bulan.

2. $N A B$ per unit yang didapat secara bulanan tersebut digunakan sebagai dasar untuk melakukan perhitungan return per reksadana. Perhitungan Return Realisasi (Realized Return) diperoleh dengan menggunakan persamaan (2.3) dan Perhitungan Return Harapan (Expected Return) diperoleh dengan menggunakan persamaan (2.4).

3. Menghitung tingkat resiko portofolio per reksadana (standard deviasi) dengan menggunakan persamaan (2.5) dan (2.6).

4. Menghitung tingkat risk free dengan menggunakan persamaan (2.7)

5. Menghitung penilaian kinerja reksadana dengan metdode sharpe menggunakan per samaan (2.8).

6. Melakukan analisis statistik deskriptif.

7. Melakukan Uji Normalitas

Uji normalitas dilakukan untuk mengetahui apakah data terdistribusi 
Putra, et al/Jurnal Ekonomi Syariah Teori dan Terapan Vol. 3 No. 9 September 2016: 683-698; PERBANDINGAN KINERJA REKSADANA SYARIAH DI INDONESIA MENGGUNAKAN METODE SHARPE (Studi Kasus Reksadana Syariah Saham, Reksadana Syariah Pendapatan Tetap dan Reksadana Syariah Campuran periode 2012-2014)

normal. Penelitian yang baik adalah penelitian yang datanya terdistribusi secara normal.

8. Melakukan uji Anova pada perhitungan kinerja reksadana dengan metode sharpe.

\section{Hasil dan Pembahasan}

\section{Uji Nrormalitas}

Sebelum melakukan pengujian hipotesis, terlebih dahulu dilakukan pengujian normalitas untuk memenuhi asumsi uji ANOVA. Uji normalitas yang dilakukan untuk melihat apakah data yang digunakan untuk penelitian ini terdistribusi normal. Dalam penelitian ini metode uji normalitas yang digunakan adalah uji Kolmogorov-Smirnov. Suatu data memenuhi distribusi normal jika memiliki nilai signifikan KolmogorovSmirnov lebih dari 0,05.

Dalam penelitian ini uji normalitas diterapkan pada hasil perhitungan ukuran kinerja shrape pada reksadana syariah saham, reksadana syariah pendapatan tetap dan reksadana syariah campuran. Berikut hasil uji normalitas KolmogorovSmirnov data ukuran kinerja sharpe pada reksadana syariah saham, reksadana syariah pendapatan tetap dan reksadana syariah campuran.

Tabel 1.

Hasil Uji Normalitas Kolmogorov-Smirnov

\begin{tabular}{|l|c|c|c|}
\hline Jenis Reksadana Syariah & N & Asymp. Sig. & Hasil \\
\hline Saham & 36 & 0,979 & Normal \\
\hline Pendapatan Tetap & 36 & 0,111 & Normal \\
\hline Campuran & 36 & 0,203 & Normal \\
\hline
\end{tabular}

Sumber: Data diolah
Berdasarkan tabel 4.1 pengujian normalitas dengan metode KolmogorovSmirnov menjelaskan bahwa seluruh hasil pengujian normalitas menunjukan nilai signifikan > 0,05 yang artinya data kinerja reksadana syariah saham, kinerja reksadana syariah pendapatan tetap dan kinerja reksadana syariah campuran memenuhi distribusi normal. Oleh Karena itu, dikarenakan memenuhi asumsi ANOVA, maka selanjutnya uji hipotesis menggunakan ANOVA bisa dilakukan.

\section{Uji Hipotesis}

Pengujian Hipotesis pada penelitian ini menggunakan uji $F$ (ANOVA) untuk menguji perbedaan kinerja reksadana syariah saham, reksadana syariah pendapatan tetap dan reksadana syariah campuran menggunakan metode sharpe. Pada uji $F$ (ANOVA) apabila nilai probabilitas $>0,05$ maka $\mathrm{H}_{0}$ diterima. Dan sebaliknya apabila nilai probabilitas $<0,05$ maka $\mathrm{H}_{0}$ ditolak. Sehingga terdapat dua hipotesis dalam penelitian ini yaitu:

$\mathrm{H}_{0}$ : Tidak ada perbedaan kinerja antara reksadana syariah saham, reksadana syariah campuran, dan reksadana syariah pendapatan tetap dengan menggunakan metode sharpe pada tahun 2012 , 2013, 2014.

$\mathrm{H}_{1}$ : Ada perbedaan kinerja antara reksadana syariah saham, reksadana syariah campuran, dan reksadana syariah pendapatan tetap dengan menggunakan metode sharpe pada tahun 2012 , 2013, 2014. 
Putra, et al/Jurnal Ekonomi Syariah Teori dan Terapan Vol. 3 No. 9 September 2016: 683-698; PERBANDINGAN KINERJA REKSADANA SYARIAH DI INDONESIA MENGGUNAKAN METODE SHARPE (Studi Kasus Reksadana Syariah Saham, Reksadana Syariah Pendapatan Tetap dan Reksadana Syariah Campuran periode 2012-2014)

Tabel 2.

Hasil Uji ANOVA Kinerja Reksadana Syariah Saham, Reksadana Syariah Pendapatan Tetap dan Reksadana Syariah Campuran Menggunakan Metode Sharpe

\begin{tabular}{|l|r|r|r|l|l|}
\hline & Sum of Squares & Df & Mean Square & F & Sig. \\
\hline Between Groups & 8.363 & 2 & 4.181 & .683 & .507 \\
Within Groups & 642.937 & 105 & 6.123 & & \\
Total & 651.300 & 107 & & & \\
\hline
\end{tabular}

Sumber: Data diolah

Pada tabel 4.2 hasil uji ANOVA data kinerja reksadana syariah saham, reksadana syariah pendapatan tetap dan reksadana syariah campuran menggunakan metode sharpe menghasilkan angka probabilitas 0,507. Dikarenakan nilai probabilitas $>0,05$ maka $\mathrm{H}_{0}$ diterima. Atau dapat disimpulkan tidak ada perbedaan kinerja antara reksadana syariah saham, reksadana syariah campuran, dan reksadana syariah pendapatan tetap dengan menggunakan metode sharpe pada tahun 2012, 2013, 2014.

\section{Pembahasan}

Untuk uji hipotesis perbandingan kinerja reksadana syariah saham, reksadana syariah pendapatan tetap dan reksadana syariah campuran menggunakan metode sharpe periode 2012 hingga 2014 hasilnya adalah tidak terdapat perbedaan kinerja reksadana syariah saham, reksadana syariah pendapatan tetap dan reksadana syariah campuran periode 2012 hingga 2014. Hal ini menunjukkan bahwa nilai uji $F$ (ANOVA) kinerja reksadana syariah saham, reksadana syariah pendapatan tetap dan reksadana syariah campuran menggunakan metode sharpe signifikansinya sebesar 0,507. Dikarenakan nilai signifikansi uji $\mathrm{F}$ yang lebih besar (>) dari a 0,05 yang berarti bahwa $\mathrm{H}_{0}$ diterima dan $\mathrm{H}_{1}$ ditolak.

Hal ini terjadi dikarenakan return yang ada pada tiap reksadana syariah, diimbangi dengan resiko yang sepadan. Dan resiko tersebut (standard deviasi) pada metode sharpe digunakan sebagai pembagi. Hal tersebut sesuai dengan penjelasan Tandelilin (2010 : 494) yang menjelaskan bahwa untuk mencari kinerja menggunakan metode sharpe yaitu dengan cara membagi premi resiko portofolio (sama dengan selisih rata-rata tingkat keuntungan portofolio dengan rata-rata bunga bebas resiko) dengan standar deviasinya (resiko total).

Tingginya return yang diiringi tingkat resiko yang tinggi sesuai dengan pernyataan Tandelilin menjelaskan bahwa "dalam melakukan investasi, perlu dilakukan penghitungan secara akurat dalam memprediksi risk dan return yang dihasilkan oleh aset. Semakin tinggi resiko yang ditanggung oleh investor, maka akan semakin tinggi keuntungan yang akan diisyaratkan oleh investor. Hal ini sesuai dengan konsep high risk, high return". Hal tersebut sudah dijelaskan dalam kaidah fiqih islam bahwa resiko akan selalu melekat pada setiap investasi. Dzajuli (2006:103) menjelaskan bahwa kaidah fiqih "al ghunmu bil ghumri", artinya resiko akan 
Putra, et al/Jurnal Ekonomi Syariah Teori dan Terapan Vol. 3 No. 9 September 2016: 683-698; PERBANDINGAN KINERJA REKSADANA SYARIAH DI INDONESIA MENGGUNAKAN METODE SHARPE (Studi Kasus Reksadana Syariah Saham, Reksadana Syariah Pendapatan Tetap dan Reksadana Syariah Campuran periode 2012-2014)

selalu menyertai setiap ekspetasi return (investasi) atau imbal hasil.

Tabel 3.

Rata - rata Return Reksadana Syariah Tahun $2012-2014$

\begin{tabular}{|l|r|r|r|r|}
\hline & 2012 & 2013 & 2014 & Rata- rata \\
\hline Reksadana syariah saham & 13,207 & $-3,022$ & 21,996 & 10,7271 \\
\hline Rekssadana syariah pendapatan tetap & 7,371 & $-0,874$ & 6,633 & 4,37686 \\
\hline Reksadana syariah campuran & 11,802 & $-2,229$ & 16,269 & 8,61404 \\
\hline
\end{tabular}

Sumber: (data diolah)

Tabel 4.

Rata - rata Standard Deviasi Reksadana Syariah Tahun 2012-2014

\begin{tabular}{|l|r|r|r|r|}
\hline & 2012 & 2013 & 2014 & Rata - rata \\
\hline Rekasdana syariah saham & 16,076 & 18,303 & 12,773 & 15,7172 \\
\hline Reksadana syarah pendapatan tetap & 5,350 & 11,250 & 6,760 & 7,7867 \\
\hline Reksadana syariah campuran & 15,615 & 16,567 & 13,522 & 15,2344 \\
\hline
\end{tabular}

Sumber: (data diolah)

Tabel 4.3 menjelaskan bahwa rata rata return tertinggi periode 2012 dan 2014 berada pada reksadana syariah saham. Akan tetapi, bila dilihat dari segi resiko pada tabel 4.4 menjelaskan bahwa rata rata resiko tertinggi periode 2012 hingga 2014 juga terdapat reksadana syariah saham. Sehingga, setinggi apapun tingkat return yang diberikan, apabila diimbangi dengan tingkat resiko yang tinggi pula maka akan menghasilkan nilai kinerja sharpe yang tidak jauh berbeda dengan reksadana syariah yang memberikan keuntungan rendah dengan resiko yang rendah.

Tabel 5. Perhitungan Rata - rata Kinerja

Reksadana Syariah Menggunakan Metode Sharpe per Bulan periode 2012 2014

\begin{tabular}{|l|r|r|r|c|}
\cline { 2 - 5 } \multicolumn{1}{c|}{} & 2012 & 2013 & 2014 & Rata - rata \\
\hline Reksdana syariah saham & 1,36 & $-0,27$ & 1,08 & 0,72 \\
\hline Reksadana syariah pendapatan tetap & 0,67 & $-0,22$ & $-0,09$ & 0,12 \\
\hline Reksadana syariah campuran & 0,53 & $-0,84$ & 0,73 & 0,14 \\
\hline
\end{tabular}

Akan tetapi, berdasarkan hasil perhitungan perbandingan kinerja ketiga jenis reksadana syariah pada tabel 4.5 menjelaskan bahwa perhitungan rata rata kinerja reksadana syariah menggunakan metode sharpe per bulan pada tahun 2012 dan 2014 tertinggi berada pada reksadana syariah saham yaitu sebesar 1,36 pada tahun 2012 dan 1,08 pada tahun 2014. Akan tetapi, pada tahun 2013, kinerja pada reksadana syariah saham mengalami penurunan dari tahun sebelumnya. Pada tahun 2013, hasil perhitungan rata - rata kinerja reksadana syariah saham menggunakan metode sharpe sebesar -0,27. Hal tersebut dikarenakan, pada tahun 2013 return reksadana syariah saham bernilai negatif, dan resiko reksadana syariah saham di tahun 2013 juga tertinggi di antara dua jenis reksadana syariah lainnya.

Untuk reksadana syariah pendapatan tetap, pada tahun 2012 hasil perhitungan kinerjanya sebesar 0,67 . Nilai tersebut mengalahkan hasil perhitungan rata - rata kinerja reksadana syariah campuran per bulan dengan nilai kinerja 0,53 . Hal tersebut terjadi dikarenakan pada tahun 2012 rata - rata resiko per bulan pada reksadana syariah campuran sangat tinggi sebesar 1,30123\%, nilai resiko tersebut hampir mendekati rata - rata resiko pada reksadana syariah saham. Pada tahun 2013, perhitungan rata - rata kinerja reksadana syariah dengan metode sharpe per bulan terendah terjadi pada reksadana syariah campuran sebesar 0,84 . Hal tersebut dikarenakan rata - rata 
return per bulan tahun 2013 pada

reksadana syaraih campuran tidak sebanding dengan rata - rata resiko per bulan yang cukup besar pada reksadana tersebut.

Bila dilihat dari rata - rata kinerja per bulan pada tiap tahun untuk ketiga jenis reksadana syariah mengalami hasil kinerja yang fluktuatif. Akan tetapi, bila dilihat dari rata - rata kinerja reksadana syariah menggunakan metode sharpe per bulan dari tahun 2012 hingga 2014 secara keseluruhan, reksadana syariah saham nilai kinerjanya memiliki nilai yang paling tinggi yaitu 0,72. Reksadana syariah campuran mendapatkan nilai rata - rata kinerja per bulan dari tahun 2012 hingga 2014 sebesar 0,14. Hasil tersebut berbeda selisih 0,02 lebih tinggi dari hasil perhitungan rata - rata kinerja reksadana syariah pendapatan tetap per bulan dari tahun 2012 hingga 2014 sebesar 0,12.

Ibnu Taimiyah dalam Badan Litbang dan Diklat Kementrian Agama RI dengan Majelis Ulama Indonesia (MUI) (2012: 166):

"syariah datang dengan membawa kemaslahatan dan menyempurnakannya, menghilangkan kerusakan dan meminimalisirnya, mengutamakan kebaikan yang lebih dan kemudharatan yang sedikit, memilih kemaslahatan yang lebih besar dengan membiarkan yang lebih kecil, dan menolak kemudharatan yang lebih besar dengan memilih yang lebih kecil".

Investasi merupakan salah satu ajaran dari konsep Islam (Huda dan Edwin 2007:17). Hal tersebut dijelaskan secara tersirat dalam firman Allah surat Al -
Lukman ayat 34: :

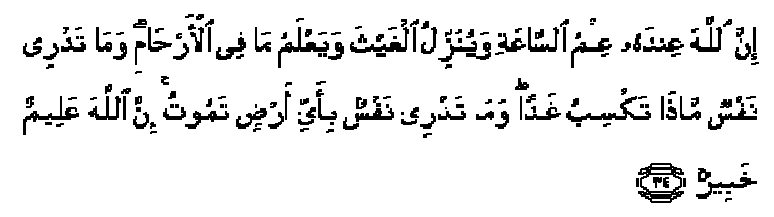

inna'l-Lāha 'indahū 'ilmu's-sā'ati wa-

yunazzilu'l-gaiśa wa-ya'lamu mā fi I-

'arḥāmi wa-mā tadrī nafsun māżā taksibu gadan wa-mā tadrī nafsun bi-'ayyi 'arḍin tamūtu 'inna'l-Lāha 'alimun khabìr

"Sesungguhnya Allah, hanya pada sisi-Nya sajalah pengetahuan tentang hari Kiamat; dan Dia-lah yang menurunkan hujan, dan mengetahui apa yang ada dalam rahim. dan tiada seorangpun yang dapat mengetahui (dengan pasti) apa yang akan diusahakannya besok dan tiada seorangpun yang dapat mengetahui di bumi mana Dia akan mati. Sesungguhnya Allah Maha mengetahui lagi Maha Mengenal"(Al-Lukman:34)

Dari ayat di atas, Huda dan Edwin (2007:7) menjelaskan secara tegas Allah menyatakan bahwa tiada seorang pun di alam semesta ini yang dapat mengetahui apa yang akan diperbuat, diusahakan serta kejadian apa yang akan terjadi pada hari esok. Sehingga dengan ajaran tersebut manusia diperintahkan untuk melakukan investasi sebagai bekal dunia akhirat.

Bila dihubungkan antara kaidah fikih dan ayat Luqman:34, maka didapatkan penjelasan bahwa dalam islam, investasi sangat dianjurkan. Akan 
Putra, et al/Jurnal Ekonomi Syariah Teori dan Terapan Vol. 3 No. 9 September 2016: 683-698; PERBANDINGAN KINERJA REKSADANA SYARIAH DI INDONESIA MENGGUNAKAN METODE SHARPE (Studi Kasus Reksadana Syariah Saham, Reksadana Syariah Pendapatan Tetap dan Reksadana Syariah Campuran periode 2012-2014)

tetapi dalam berinvestasi juga harus menimbang antara resiko dan return yang akan didaptakan. Apabila para investor akan menginvestasikan dananya pada suatu jenis reksadana syariah, akan tetapi resiko yang didapatkan lebih besar dibanding return yang akan diterimanya, maka investor harus memilih jenis reksadana syariah yang lainnya. Agar maslahat yang didapatkan lebih besar dibanding mudharatnya.

$$
\text { Makin tinggi hasil pengukuran }
$$

sharpe, makin baik kinerja suatu portofolio (Tandelilin, 2010:493). Sehingga dapat disimpulkan bahwa dari hasil perhitungan rata - rata kinerja reksadana syariah per bulan dari tahun 2012 hingga 2014, reksadana syariah saham adalah reksadana yang memiliki kinerja terbaik dibanding kedua jenis reksadana lainnya. Hal tersebut dikarenakan dalam pehitungan rata - rata kinerja reksadana syariah menggunakan metode sharpe periode 2012 hingga 2014 nilainya 0,72. Nilai kinerja tersebut lebih tinggi dibandingkan dari nilai kedua jenis kenerja reksadana syariah lainnya.

\section{SIMPULAN}

1. Menggunakan hasil uji $F$ (ANOVA) didapatkan kesimpulan bahwa tidak ada perbedaan kinerja antara reksadana syariah saham, reksadana syariah campuran, dan reksadana syariah pendapatan tetap dengan menggunakan metode sharpe pada tahun 2012, 2013, 2014.

2. Berdasarkan hasil perhitungan rata rata kinerja reksadana syariah per bulan dari tahun 2012 hingga 2014, reksadana syariah saham adalah reksadana yang memiliki kinerja terbaik dibanding kedua jenis reksadana lainnya. Nilai pehitungan rata - rata kinerja reksadana syariah menggunakan metode sharpe periode 2012 hingga 2014 untuk reksadana syariah saham adalah 0,72. Nilai kinerja tersebut lebih tinggi dibandingkan dari nilai kedua jenis kenerja reksadana syariah lainnya.

\section{DAFTAR PUSTAKA}

Achsien, Iggi H. 2000. Investasi Syariah di Pasar Modal, Menggagas konsep dan Praktek Manajemen portofolio Syariah. Jakarta: Gramedia Pustaka Utama.

Anshori, Muslich dan Sri Iswati. 2009. Buku Ajar Metodologi Penelitian Kuantitatif. Surabaya: Pusat Penerbitan dan Percetakan Unair.

Badan Litbang dan Diklat Kementrian Agama RI dengan Majelis Ulama Indonesia (MUI). 2012. Fatwa Majelis Ulama Indonesia MUI dalam Prespektif Hukum dan Perundang Undangan. Jakarta: Badan Litbang dan Diklat Kementrian Agama RI dengan Majelis Ulama Indonesia (MUI)

Danim, Sudarwan. 1997. Metode Penelitian Untuk IImu-llmu Perilaku Acuan Dasar Bagi Mahasiswa Program Sarjana dan Peneliti Pemula. Cetakan Pertama. Jakarta: Bumi Aksara.

Darmadji, Ali dan Hendy MF. 2001. Pasar Modal di Indonesia. Jakarta: Salemba Empat. 
Putra, et al/Jurnal Ekonomi Syariah Teori dan Terapan Vol. 3 No. 9 September 2016: 683-698; PERBANDINGAN KINERJA REKSADANA SYARIAH DI INDONESIA MENGGUNAKAN METODE SHARPE (Studi Kasus Reksadana Syariah Saham, Reksadana Syariah Pendapatan Tetap dan Reksadana Syariah Campuran periode 2012-2014)

Dzajuli, A. 2006. Kaidah - Kaidah Fikih: Kaidah - Kaidah Hukum Islam dalam Masalah - Masalah yang Prakris. Jakarta: Kencana

Fardiansyah, Tedy. 2002. Kiat Dan Strategi Menjadi Investor Piawai. Jakarta: PT Elex Media Komputindo.

Firdaus, Muhammad, dkk. 2005. Investasi Halal di Reksa Dana Syariah. Jakarta : Renaisan.

Ghufron, Sofiniyah.2005. Briefcase Book Edukasi Profesional Syariah Investasi halal di Reksa Dana Syariah, Jakarta: Renaisan.

Halim, Abdul. 2005. Analisis Investasi. Jakarta: Salemba Empat.

Hasbi, Hariyandi. 2010. Kinerja Reksadana Syariah tahun 2009 di Indonesia. Jurnal Keuangan dan Perbankan, Vol. 14, No.1 Januari 2010, hal 62-73

Hamzah, Amal dan Agustunius Yohanes. 2014. Analisis Perbandingan Kinerja Reksadana Syariah dengan Reksadana Konvensional Jenis Saham pada Periode 2008 - 2012. Jurnal MIX, Volume IV: 396-409.

Hartono, Jogiyanto. 2010, Teori Portofolio dan Analisis Investasi, Yogyakarta: BPFE Yogyakarta.

Huda, Nurul dan Mustafa Edwin Nasution. 2007. Investasi Pada Pasar Modal Syariah. Jakarta: Kencana.

Indriantoro, Nur dan Bambang Supomo. 2002. Metode Penelitian Bisnis. Yogyakarta: BPFE.

Lind, et al. 2008. Teknik - teknik Statistika dalam Bisnis dan Ekonomi Menggunakan Kelompok Data Global. Edisi 13. Jakarta: Salemba Empat

Ojk.go.id (diakses 19 September 2015)

Pinastiko, Daru dan Musaroh. 2014. Analisis Pengukuran Kinerja Reksa Dana Saham dengan Metode Risk-
Adusted Return di Bursa Efek Indonesia Periode 2011-2013. Jurnal IImu Manajemen, Volume 11, Nomor $3: 20-46$

Prasetyo, Bambang dan Lina Miftahul Jannah. 2012. Metode Penelitian Kuantitatif, Jakarta: PT RajaGrafindo Persada Pusatdata.kontan.com (diakses pada 15 Desember 2015)

Santosa, Magdalena dan Amelina. 2012.

Penilaian Produk Reksa Dana dengan Menggunakan Perhitungan Jensen Alpha, Sharpe Ratio, Treynor Ratio, M-Square, dan Information Ratio. Jurnal Manajemen, Vol. 12, November 2012.

Shihab, M. Quraish. 2009. Tafsir Al-Mishbah. Pisangan Ciputat : Penerbit Lentera Hati

Singarimbun, Masri dan Sofian Efendi. 1989. Metode Penelitihan Survai. Jakarta: LP3ES

Soemitra, Andri. 2009. Bank dan Lembaga Keuangan Syariah. Jakarta : Kencana Prenada Media Group.

Sunariyah. 2006. Pengantar Pengetahuan Pasar Modal. Yogyakarta: Unit Penerbit dan Percetakan Sekolah Tinggi Ilmu Manajemen YKPN.

Sudarsono, Heri. 2004. Bank dan Lembaga Keuangan Syariah (Deskripsi dan Ilustrasi). Cet: kedua. Yogyakarta: Ekonosia.

Sugiyono. 2011. Metode Penelitian Kuantitatif Kualitatif dan R\&D. Bandung: Alfabeta.

Tandelilin, Eduardus. 2010. Portofolio dan Investasi. Yogyakarta: Kanisius.

Tuerah, Citrayani. 2013. Perbandingan Kinerja Saham LQ-45 Tahun 2012 Menggunakan Metode Jansen, Sharpe, Treynor. Jurnal EMBA, Vol.1 No.4 Desember 2013, Hal. 1444-1457 